\title{
The 132 Ma Comei-Bunbury large igneous province: Remnants identified in present-day southeastern Tibet and southwestern Australia
}

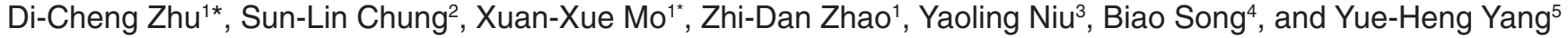 \\ ${ }^{1}$ State Key Laboratory of Geological Processes and Mineral Resources, China University of Geosciences, Beijing 100083, China \\ 2Department of Geosciences, National Taiwan University, Taipei 106, Taiwan \\ ${ }^{3}$ Department of Earth Sciences, Durham University, Durham DH1 3LE, UK \\ ${ }^{4}$ Beijing SHRIMP II Center, Institute of Geology, Chinese Academy of Geological Sciences, Beijing 100037, China \\ Institute of Geology and Geophysics, Chinese Academy of Sciences, Beijing 100029, China
}

\begin{abstract}
We report 11 new $\mathrm{U}-\mathrm{Pb}$ zircon ages obtained by sensitive high-resolution ion microprobe (SHRIMP) and laser ablation-inductively coupled plasma-mass spectrometry (LA-ICP-MS) for a large province of Early Cretaceous Comei igneous rocks consisting of basaltic lavas, mafic sills and dikes, and gabbroic intrusions together with subordinate layered ultramafic intrusions and silicic volcanic rocks exposed in the Tethyan Himalaya, southeastern Tibet. Available zircon $\mathrm{U}-\mathrm{Pb}$ ages obtained from various rocks in this province, which has an areal extent of $\sim 40,000 \mathrm{~km}^{2}(\sim 270 \mathrm{~km} \times 150 \mathrm{~km})$, indicate that the magmatism occurred ca. $132 \mathrm{Ma}$ ago, coeval with the Bunbury Basalt in southwestern Australia. Such a striking similarity in emplacement age, in combination with the tectonic reconstruction of eastern Gondwana ca. 132 Ma ago, allows us to propose that the extensive Comei igneous rocks in southeastern Tibet and the Bunbury Basalts in southwestern Australia may represent the erosional and/or deformational remnants of a large igneous province, which we call the Comei-Bunbury LIP. We argue that this newly identified LIP was likely caused by the Kerguelen mantle plume, which started in the Early Cretaceous and may have played a role in the breakup of eastern Gondwana and the development of the 132 Ma old Weissert oceanic anoxic event.
\end{abstract}

\section{INTRODUCTION}

The term large igneous province (LIP) is used to represent a variety of mafic igneous provinces with areal extents $>100,000 \mathrm{~km}^{2}$ (Coffin and Eldholm, 1994; Bryan and Ernst, 2008) or $>50,000 \mathrm{~km}^{2}$ (Sheth, 2007) as the result of extensive decompressive melting in response to ascending mantle plumes and lithospheric extension (e.g., Richards et al., 1989; White and McKenzie, 1989). The generation of many plume-related LIPs has been linked to continental breakup, as exemplified by the Kerguelen mantle plume initiation that played a role in rifting the Gondwana and opening the eastern Indian Ocean (Storey, 1995). Along with the immense Kerguelen Plateau being formed within the nascent Indian Ocean basin, this plume activity may have also resulted in the Rajmahal Traps in northeastern India (Kent et al., 2002) and the Bunbury Basalt in southwestern Australia (Frey et al., 1996) during the rifting event. However, correlation of the Bunbury Basalt with the other two outputs has been often questioned because the former began erupting ca. 132 Ma ago (Frey et al., 1996; Coffin et al., 2002), whereas no rocks from both the Rajmahal Traps and Kerguelen Plateau are older than $120 \mathrm{Ma}$ (cf. Ingle et al., 2004). In this paper we present 11 new zircon U-Pb ages

*E-mail: dchengzhu@163.com; moxx38@yahoo. com obtained by sensitive high-resolution ion microprobe (SHRIMP) and laser ablation-inductively coupled plasma-mass spectrometry (LA-ICPMS) for the extensive Early Cretaceous igneous rocks around the Comei area in southeastern Tibet. We argue that the contemporaneous igneous rocks dispersed in southeastern Tibet and southwest Australia are genetically related and constitute the erosional and/or deformational remnants of a large igneous province, which we call the Comei-Bunbury LIP, emplaced above a mantle plume in eastern Gondwana ca. $132 \mathrm{Ma}$ ago. Its possible link with the Kerguelen mantle plume and implications for the breakup of eastern Gondwana and the development of the Weissert oceanic anoxic event are also explored.

\section{BACKGROUND AND SAMPLES}

The Early Cretaceous igneous rocks exposed in southeastern Tibet have been documented for years (Bureau of Geology and Mineral Resources of Xizang Autonomous Region, 1993) as an important component within the eastern Tethyan Himalayan sequence located between the Yarlung Zangbo suture to the north and the Greater Himalayas to the south (Fig. 1A). However, no good quality data on these rocks have been available until recently (Zhu et al., 2005; Jiang et al., 2006); these data formed a basis for subsequent investigations (Zhu et al., 2007, 2008a) that identified plume signatures in local areas (e.g., Rimowa village and Cona areas; Fig. 1B) of southern Tibet. The new data obtained in this study together with field observations and consideration in a global context further suggest that the rocks in southeastern Tibet and the Bunbury Basalt in southwestern Australia are temporally related and constitute the erosional and/or deformational remnants of a large igneous province, which we call the Comei-Bunbury LIP. Like other preCenozoic LIPs that have lost most of their volcanic components owing to tectonic deformation or erosion (Ernst, 2007; Bryan and Ernst, 2008), the remnant Comei LIP in southeastern Tibet is dominated by dismembered mafic lava flows, sills, and dikes, with subordinate ultramafic and silicic rocks of Early Cretaceous age belonging to Sangxiu and Lakang Formations (Wan et al., 2005; Zhu et al., 2008a) (Fig. 1B).

In this study, we collected igneous rock samples along three north-south transects from $28^{\circ} \mathrm{N}$ to $29^{\circ} \mathrm{N}$ and $90^{\circ} 30^{\prime} \mathrm{E}$ to $92^{\circ} \mathrm{E}$ in the Comei LIP (Fig. 1B). Of all the 70 samples with geochemical data, 11 samples that include 5 diabasic dikes, 4 gabbros, a pyroxenite, and a dacite were successfully extracted for zircons for SHRIMP and LA-ICP-MS U-Pb dating. Sample details and zircon $\mathrm{U}-\mathrm{Pb}$ age data are summarized in GSA Data Repository Table DR1. ${ }^{1}$ Actual analyses and data reduction procedures are given in Tables DR2 and DR3. Zircons from mafic and ultramafic samples show similar crystal forms with no resorption or inherited cores (Figs. DR1 and DR2) and exhibit low to very high uranium (16-11,853 ppm) and thorium (24-22,230 ppm) contents, yielding $\mathrm{Th} / \mathrm{U}$ ratios from 0.77 to 5.24 (Tables DR2 and DR3). Zircons from a dacite sample exhibit different crystal forms, including long columnar and inherited cores (Fig. DR2e).

${ }^{1}$ GSA Data Repository item 2009138, summary of zircon U-Pb isotopic ages (Table DR1), methods and zircon SHRIMP U-Pb data (Table DR2), methods and zircon LA-ICP-MS U-Pb data (Table DR3), cathodoluminescence (CL) images of zircon SHRIMP dating (Fig. DR1), CL images of zircon LA-ICP-MS dating (Fig. DR2), concordia plot of zircon SHRIMP dating (Fig. DR3), and concordia plot of zircon LA-ICP-MS dating (Fig. DR4), is available online at www.geosociety.org/pubs/ft2009.htm, or on request from editing@geosociety.org or Documents Secretary, GSA, P.O. Box 9140, Boulder, CO 80301, USA. 


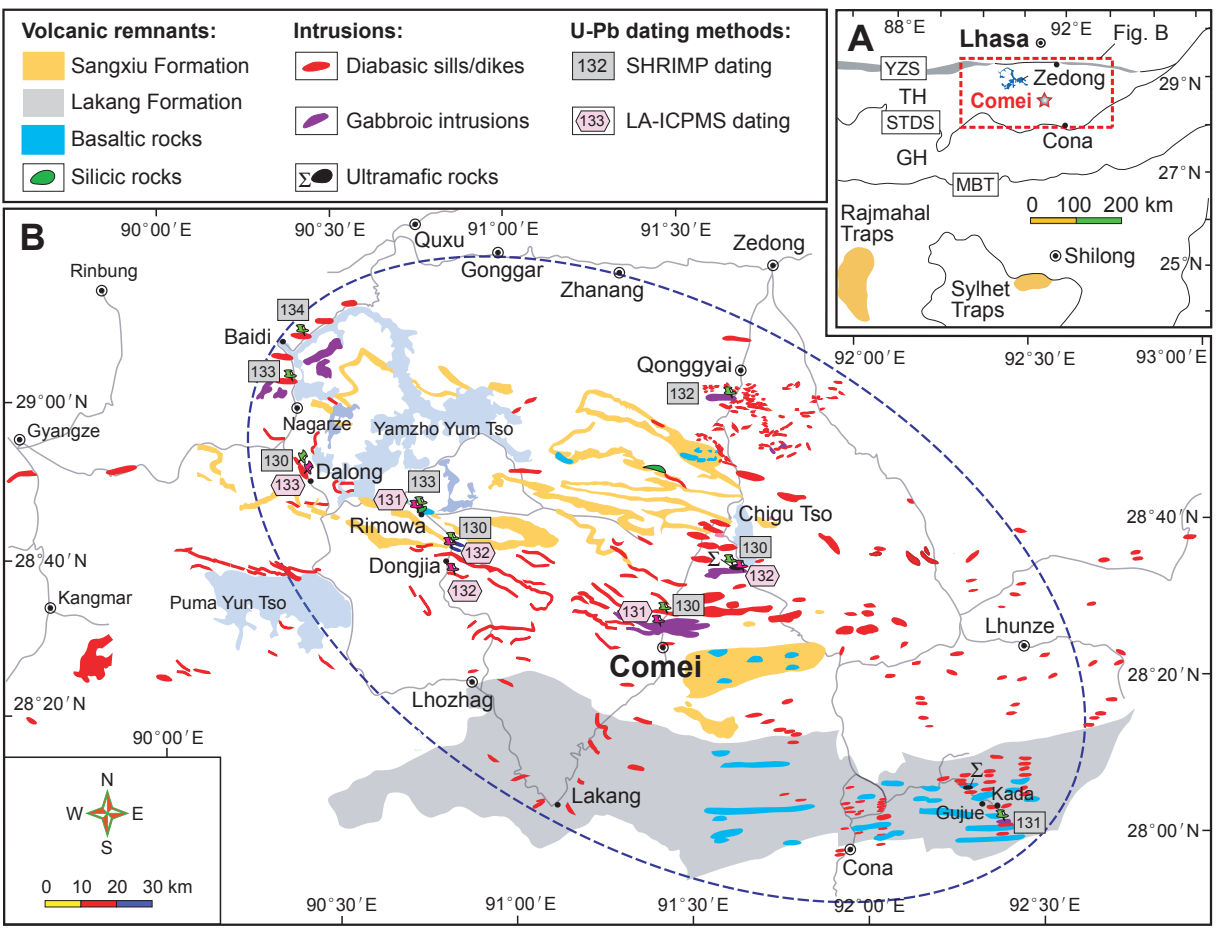

Figure 1. A: Sketch of tectonic map of southeastern Tibet, showing location of remnant Comei large igneous province (LIP), and Rajmahal and Sylhet Traps of northeastern India (Coffin et al., 2002; Zhu et al., 2008a). B: Simplified geology map showing spatial extent (dashed ellipse) and distributions of $\sim 132$ Ma old igneous rocks of the remnant Comei LIP. SHRIMPsensitive high-resolution ion microprobe; LA-ICP-MS-laser ablation-inductively coupled plasma-mass spectrometry; YZS-Yarlung Zangbo suture; TH-Tethyan Himalaya; STDSSouth Tibet detachment system; GH—Greater Himalaya; MBT—Main Boundary thrust.

They exhibit variable uranium (51-373 ppm) and thorium (64-370 ppm) contents, yielding $\mathrm{Th} / \mathrm{U}$ ratios from 0.21 to 1.34 (Table DR3). All these features are consistent with the zircons being magmatic in origin (Hoskin and Black, 2000). Thus, the interpretation of the zircon U-Pb isotopic data (see following) is straightforward, and the obtained ${ }^{206} \mathrm{~Pb} /{ }^{238} \mathrm{U}$ ages are interpreted as dating the time of crystallization of the zircons, and thus the time of emplacement of the host rocks. Uncertainties on individual analyses are reported at the $1 \sigma$ level; mean ages for pooled ${ }^{206} \mathrm{~Pb} /{ }^{238} \mathrm{U}$ results are reported at the $2 \sigma$ level to indicate the host rock crystallization ages (Tables DR1 and DR3; Figs. DR3 and DR4).

\section{ZIRCON U-PB AGES OF THE REMNANT COMEI LIP}

\section{Volcanic Remnants}

The remnant volcanic rocks are interbedded with the Early Cretaceous clastic sedimentary rocks in Sangxiu and Lakang Formations (Wan et al., 2005; Zhu et al., 2008a), which are distributed in the northern and southern parts of the remnant Comei LIP (Fig. 1B). The volcanic rocks are bimodal, mostly basalts with some silicic varieties (Zhu et al., 2007). The basalts are generally massive; however, lavas with pillowed structure are also observed. The basalts vary in thickness from tens of meters to $\sim 600 \mathrm{~m}$ (Zhu et al., 2008a). The silicic rocks form a 130-m-thick succession of rhyodacite and rhyolite and show columnar jointing. Two silicic samples from Rimowa village give a SHRIMP zircon U-Pb age of $133 \pm 3$ Ma old (Zhu et al., 2005) and a LAICP-MS U-Pb age of $131 \pm 5$ Ma old (Fig. 1B).

\section{Mafic Intrusions}

Voluminous mafic intrusions (include diabasic sills, dikes, and gabbros) of the same or similar ages intruded both the variably deformed Early Triassic-Lower Jurassic sedimentary strata, which show rapid northward changes in thickness and lithofacies, and the partly deformed Early Cretaceous sedimentary strata, which likely formed in a passive continental margin environment (Zhu et al., 2007) from the western Yamzho Yum Tso to southeastern Cona in southeastern Tibet (Fig. 1B). The sills and dikes with average widths $>10 \mathrm{~m}$ extend generally in an east-west direction, mostly parallel to the strike of regional strata and also the Himalayan tectonic zone.

In the western Comei LIP, the Late Triassic strata are intruded by diabasic dikes, two of which, from the vicinity of Baidi village (Fig. 1B), give SHRIMP zircon U-Pb ages of $134.1 \pm$ 2.0 Ma old and $133.4 \pm 1.6$ Ma old (Jiang et al., 2006). To the south, near Dalong village (Fig. 1B), diabasic dikes that intruded the Early to
Middle Triassic strata give a SHRIMP U-Pb age of $129.5 \pm 1.3 \mathrm{Ma}$ old and a LA-ICP-MS U-Pb age of $133 \pm 2$ Ma old. In the central Comei LIP north of Dongjia village (Fig. 1B), gabbros emplaced within the Middle Jurassic strata give a SHRIMP U-Pb age of $129.7 \pm 1.4 \mathrm{Ma}$ old and a LA-ICP-MS U-Pb age of $132 \pm 3 \mathrm{Ma}$ old. To the south of Dongjia village, a diabasic dike gives a LA-ICP-MS U-Pb age of $132 \pm 2$ Ma old. To the north of Comei County in the central Comei LIP, the Early-Middle Jurassic strata were intruded by gabbros (Fig. 1B), one of which gives a LA-ICP-MS U-Pb age of 131 \pm 1 Ma old. Farther north, a diabase dike yields a SHRIMP U-Pb age of $130.2 \pm 2.0 \mathrm{Ma}$ old. To the south of Chigu Tso, a gabbro that intruded the Early Jurassic strata gives a LA-ICP-MS $\mathrm{U}-\mathrm{Pb}$ age of $132 \pm 1 \mathrm{Ma}$ old farther northeast of Chigu Tso (Fig. 1B). At the Qonggyai reservoir of the northern Comei LIP, a gabbroic dike emplaced within the strongly deformed Late Triassic strata gives a SHRIMP U-Pb age of $132.1 \pm 1.0 \mathrm{Ma}$ old. To the south of Kada village in the southeastern Comei LIP (Fig. 1B), a gabbroic intrusion gives a SHRIMP U-Pb age of 131.1 \pm 6.1 Ma old (Zhu et al., 2008a).

\section{Ultramafic Rocks}

Ultramafic rocks include layered pyroxenites and picrite porphyrites that intruded the Jurassic sedimentary strata in the central Comei LIP and the Lakang Formation sedimentary rocks in the southeastern Comei LIP (Fig. 1B). A pyroxenite sample in southwest Chigu Tso gives a SHRIMP zircon U-Pb age of $130 \pm 2.0$ Ma old.

In summary, we have obtained 11 new age determinations on rocks of the remnant Comei LIP using the SHRIMP and LA-ICP-MS zircon U-Pb methods (Tables DR1 and DR3; Figs. DR3 and DR4). These new age dates, in combination with four published age data, agree within analytical uncertainty and give a weighted mean of $131.5 \pm 0.8$ Ma old (Fig. 2).

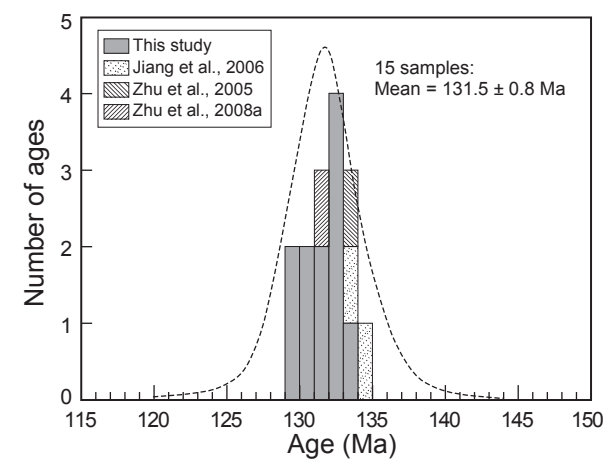

Figure 2. Zircon $\mathrm{U}-\mathrm{Pb}$ ages of the remnant Comei large igneous province (LIP) rocks. Age value of $131.5 \pm 0.8 \mathrm{Ma}$ ago is weighted mean of 15 samples and is interpreted as representing the timing of extensive magmatism of Comei LIP. 
These 15 age dates are from samples distributed over a region as much as $270 \mathrm{~km}$ long and $150 \mathrm{~km}$ wide with an areal extent of $\sim 40,000$ $\mathrm{km}^{2}$ in southeastern Tibet. The outer boundary of this area is marked by the diabasic dikes in western Yamzho Yum Tso, the gabbros in Kada village, and the gabbroic dikes to the south of Qonggyai County (dashed ellipse in Fig. 1B). Note that the diabases located farther west in the Gyangze and Kangmar areas (outside the ellipse; Fig. 1B) are similar and are also likely part of the Comei LIP, although this remains to be confirmed by dating.

\section{DISCUSSION}

\section{Spatial Extent of the Comei LIP and Associated Magmatism}

The Sangxiu Formation basalts exposed in Rimowa village are geochemically similar to the high-Ti mafic rocks widely distributed in Cona area (Zhu et al., 2007, 2008a). This geochemical similarity is also shared by high-Ti group rocks elsewhere in southeastern Tibet (Zhu et al., 2008b). While most outcrops of the remnant Comei LIP (Fig. 1B) are undated, the field relationships and geochemical similarities of all these igneous rocks suggest that they are coeval and cogenetic. The Tethyan Himalaya is a tectonically active terrain in response to the India-Asia collision and continued convergence (Hodges, 2000). Therefore, significant tectonic shortening accompanied by deep erosion has occurred since the emplacement of the LIP. This explains why the dominant rock assemblages here are deep-level intrusives rather than basaltic flows. For all these reasons, we can infer with confidence that the original Comei LIP must have occupied a substantially larger area $\left(>40,000 \mathrm{~km}^{2}\right.$ ) during their emplacement, probably exceeding the minimum level of 100,000 $\mathrm{km}^{2}$ for strict classification as a LIP (Coffin and Eldholm, 1994; Bryan and Ernst, 2008).

The remnant Comei LIP was paleogeographically located in northeastern Greater India, positioned adjacent to the present-day southwestern margin of Australia in widely cited reconstructions of ca. 132 Ma ago eastern Gondwana (Fig. 3) (cf. Schettino and Scotese, 2001; Coffin et al., 2002). The Bunbury Basalts in southwestern Australia were emplaced ca. 132 Ma ago (Frey et al., 1996; Coffin et al., 2002), coeval with the extensive magmatism documented in the remnant Comei LIP (Fig. 2). Interpreted Lower Cretaceous volcanic rocks capping the Naturaliste Plateau, off the southwestern tip of Australia (Fig. 3), are inferred to be correlated with the Bunbury Basalts (Coleman et al., 1982; Coffin et al., 2002). Such geographical and age distributions of the magmatism of ca. $132 \mathrm{Ma}$ ago allow us to link the Comei LIP and the Bunbury Basalts

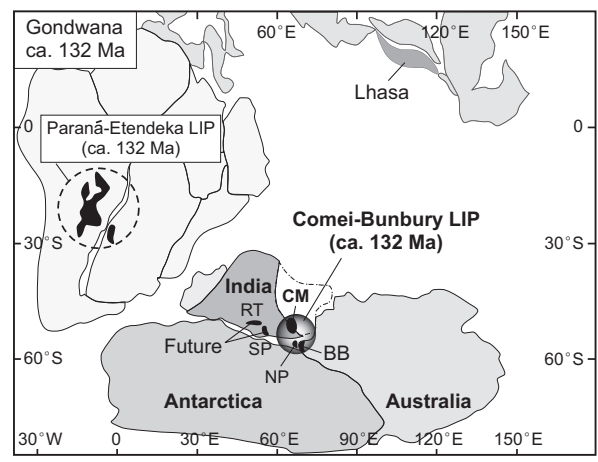

Figure 3. Generalized plate tectonic reconstruction ( $132 \mathrm{Ma}$ old; modified from Schettino and Scotese, 2001) of Gondwana, showing locations of Paraná-Etendeka large igneous province (LIP) and Comei-Bunbury LIP identified in this study. Known locations of Shillong Plateau (SP), Rajmahal Traps (RT), Naturaliste Plateau (NP), and Bunbury Basalt (BB) are labeled. Location of remnant Comei LIP (CM) is shown in view of presentday spatial extent and Cenozoic shortening relative to Rajmahal Traps province.

(and/or the Naturaliste Plateau volcanic rocks) into a single Comei-Bunbury LIP (Fig. 3).

\section{Duration of the Comei-Bunbury LIP Magmatism}

Although precise age data are unavailable for basalts in the Sangxiu and Lakang Formations, the basalt in the Sangxiu Formation is inferred to be only slightly older than the 131-133 Ma old dacite. This is because the sedimentary unit consisting of coarse and fine clastic rocks between the underlying basalt and the overlying dacite is very minor and is only $\sim 70 \mathrm{~m}$ thick where exposed in Rimowa village (Fig. 1B; Zhu et al., 2007), and could have been formed within a short period (e.g., <1-3 Ma) in a continental rift setting (Zhu et al., 2007). Therefore, given the analytical uncertainties, the zircon U-Pb age of dacite ( 131-133 Ma old) can be used to represent the emplacement age of the basalt of the Sangxiu Formation. The 15 zircon $\mathrm{U}-\mathrm{Pb}$ age dates (including 11 new ages reported in this study and 4 ages recently published) define a short magmatic duration of 4 m.y. (i.e., between 134 and $130 \mathrm{Ma}$ ago) covering an areal extent $>\sim 40,000 \mathrm{~km}^{2}$ in southeastern Tibet (Fig. 1B), which, in combination with the 132 Ma old Bunbury Basalts in southwestern Australia, indicate that a large portion of the total igneous volume in the Comei-Bunbury LIP was probably emplaced within a short duration $(<5 \mathrm{Ma})$. Although the details remain unclear, development of the Comei-Bunbury LIP probably was controlled by an interaction between a mantle plume and eastern Gondwana lithosphere (Frey et al., 1996; Zhu et al., 2007, 2008a).
Links to the Early Kerguelen Plume Activity

The possible relationship between the Rajmahal Traps and Kerguelen plume volcanism is less contended, but whether the Bunbury Basalt is genetically related to the Kerguelen plume is controversial largely because of the small volume of the Bunbury Basalt and its older age; 10-20 Ma older than the oldest volcanism on the Kerguelen Plateau (Ingle et al., 2004). Zircon U-Pb dates reported in this study indicate that the extensive magmatism in the remnant Comei LIP was synchronous with the Bunbury Basalts in southwestern Australia, both predating any rocks sampled from the Rajmahal Traps and the Kerguelen Plateau (Coffin et al., 2002). Early studies suggested that ca. $130 \mathrm{Ma}$ ago the Kerguelen plume was beneath the triple junction of Australia, Antarctica, and Greater India (Davies et al., 1989). New paleomagnetic results indicate that the Kerguelen plume has moved southward by $3^{\circ}-10^{\circ}$ since ca. $120 \mathrm{Ma}$ ago (Antretter et al., 2002). The estimated distance of $\sim 800-1200 \mathrm{~km}$ between the Comei LIP and the Rajmahal Traps province during Early Cretaceous time suggests that the Comei-Bunbury LIP may have been influenced by the Kerguelen plume activity at the time. If common source components for the ComeiBunbury LIP magmas and Kerguelen plume lavas are assumed (Frey et al., 1996; Ingle et al., 2004; Zhu et al., 2007, 2008a, 2008b), the plate reconstruction indicates that the ComeiBunbury LIP may have been genetically associated with the initial Kerguelen plume, which was already active before $130 \mathrm{Ma}$ ago.

\section{Implications for the Breakup of Eastern Gondwana and the Oceanic Anoxic Event}

The small volume of the known magmatism ca. $132 \mathrm{Ma}$ ago potentially related to the Kerguelen plume led some investigators (Frey et al., 1996; Coffin et al., 2002) to suggest that this stage of plume activity may not have played a role in the breakup of eastern Gondwana. However, the recognition of the Comei-Bunbury LIP, along with older volcanic rocks (older than $120 \mathrm{Ma}$ ) that are expected to exist (to be tested further via drilling into the Kerguelen Plateau; Duncan, 2002; Kieffer et al., 2002), can in fact be reconstructed to the single Kerguelen plume with an initial pulse ca. $132 \mathrm{Ma}$ ago. The extensive magmatism of the Comei-Bunbury LIP (ca. $132 \mathrm{Ma}$ ago) coincides broadly with the oldest magnetic anomaly (ca. 130.9 Ma ago) identified between northeastern Greater India and southwestern Australia (Heine and Müller, 2005). These tectonomagmatic events suggest that the Kerguelen plume activities reflected by the Comei-Bunbury LIP could have played a key role in the breakup of eastern Gondwana.

Previous studies documented a global perturbation of marine ecosystems, including biotic 
changes in nannofossils and radiolaria and positive excursions of carbon isotopes of marine carbonates in the Valanginian age (cf. Lini et al., 1992; Erba et al., 2004; Weissert and Erba, 2004). Such a perturbation has been assumed to represent the onset of the Cretaceous greenhouse Earth and was generally correlated with the magmatic activity of the Paraná-Etendeka continental flood-basalt province (132 Ma ago; Fig. 3) (see Lini et al., 1992). Subsequent works referred to this perturbation ca. $132 \mathrm{Ma}$ ago as the Weissert oceanic anoxic event (OAE) (Erba et al., 2004). The extensive magmatism of the Comei-Bunbury LIP identified by this study ( 132 Ma old) is coeval with the Weissert OAE. Although the environmental catastrophes of the Comei-Bunbury LIP require further exploration, the magmatism associated with this newly identified LIP and subsequent tectonic activity related to the breakup of eastern Gondwana could also have contributed hydrothermal biolimiting elements toward the development of the Weissert OAE.

\section{CONCLUSIONS}

Our data suggest that (1) the extensive Comei igneous rocks were emplaced ca. $132 \mathrm{Ma}$ ago in an area $>\sim 40,000 \mathrm{~km}^{2}$ in southeastern Tibet; (2) the remnant Comei LIP can be correlated with the coeval Bunbury Basalt in present-day southwestern Australia, both of which represent the erosional and/or deformational remnants of a large igneous province, which we call the Comei-Bunbury LIP; and (3) this newly identified LIP was likely caused by the Kerguelen mantle plume that started in the Early Cretaceous and may have played a role in the breakup of eastern Gondwana and the development of the Weissert OAE $132 \mathrm{Ma}$ ago.

\section{ACKNOWLEDGMENTS}

We are grateful for discussions with Ji-Feng $\mathrm{Xu}$ and constructive reviews by Richard E. Ernst (Canada), Frederick A. Frey, and Ajoy K. Baksi, and editorial handling by Andy Barth. This study was supported by the National Natural Science Foundation of China (40503005), and the National Key Project for Basic Research of China (Projects 2006CB701402, 2009CB421002, 2002CB412603).

\section{REFERENCES CITED}

Antretter, M., Steinberger, B., Heider, F., and Soffel, H., 2002, Paleolatitudes of the Kerguelen hotspot: New paleomagnetic results and dynamic modeling: Earth and Planetary Science Letters, v. 203, p. 635-650, doi: 10.1016/S0012821X(02)00841-5.

Bryan, S.E., and Ernst, R.E., 2008, Revised definition of large igneous provinces (LIPs): EarthScience Reviews, v. 86, p. 175-202, doi: 10.1016/j.earscirev.2007.08.008.

Bureau of Geology and Mineral Resources of Xizang Autonomous Region, 1993, Regional geology of Xizang (Tibet) Autonomous Region: Beijing, Geological Publishing House, p. 449-450 (in Chinese with English abstract).

Coffin, M., and Eldholm, O., 1994, Large igneous provinces: Crustal structure, dimensions and external consequences: Reviews of Geophysics, v. 32, p. 1-36, doi: 10.1029/93RG02508.

Coffin, M.F., Pringle, M.S., Duncan, R.A., Gladczenko, T.P., Storey, M., Müller, R.D., and Gahagan, L.A., 2002, Kerguelen hotspot magma output since 130 Ma: Journal of Petrology, v. 43, p. 1121-1139, doi: 10.1093/petrology/43.7.1121.

Coleman, P.J., Michael, P.J., and Mutter, J.C., 1982, The origin of the Naturaliste Plateau, southeast Indian Ocean: Implications from dredged basalts: Geological Society of Australia Journal, v. 29 , p. $457-468$.

Davies, H.L., Sun, S.S., Frey, F.A., Gautier, I., McCulloch, M.T., Price, R.C., Bassias, Y., Klootwijk, C.T., and LeClaire, L., 1989, Basalt basement from the Kerguelen Plateau and the trail of a Dupal plume: Contributions to Mineralogy and Petrology, v. 103, p. 457-469, doi: $10.1007 /$ BF01041753.

Duncan, R.A., 2002, A time frame for construction of the Kerguelen Plateau and Broken Ridge: Journal of Petrology, v. 43, p. 1109-1119, doi: 10.1093/petrology/43.7.1109.

Erba, E., Bartolini, A., and Larson, R.L., 2004, Valanginian Weissert oceanic anoxic event: Geology, v. 32, p. 149-152, doi: 10.1130/G20008.1.

Ernst, R.E., 2007, Mafic-ultramafic large igneous provinces (LIPs): Importance of the pre-Mesozoic record: Episodes, v. 30, p. 107-113.

Frey, F.A., McNaughton, N.J., Nelson, D.R., Delaeter, J.R., and Duncan, R.A., 1996, Petrogenesis of the Bunbury Basalt, Western Australia: Interaction between the Kerguelen plume and Gondwana lithosphere?: Earth and Planetary Science Letters, v. 144, p. 163-183, doi: 10.1016/0012821X(96)00150-1.

Heine, C., and Müller, R.D., 2005, Late Jurassic rifting along the Australian northwest shelf: Margin geometry and spreading ridge configuration: Australian Journal of Earth Sciences, v. 52, p. 27-39, doi: 10.1080/08120090500100077.

Hodges, K.V., 2000, Tectonics of the Himalaya and southern Tibet from two perspectives: Geological Society of America Bulletin, v. 112, p. 324 350, doi: 10.1130/0016-7606(2000)112<0324: TOTHAS $>2.3 . \mathrm{CO} ; 2$.

Hoskin, P.W.O., and Black, L.P., 2000, Metamorphic zircon formation by solid-state recrystallization of protolith igneous zircon: Journal of Metamorphic Geology, v. 18, p. 423-439, doi: 10.1046/j.1525-1314.2000.00266.x.

Ingle, S., Scoates, J.S., Weis, D., Brügmann, G., and Kent, R.W., 2004, Origin of Cretaceous continental tholeiites in southwestern Australia and eastern India: Insights from $\mathrm{Hf}$ and Os isotopes: Chemical Geology, v. 209, p. 83-106, doi: 10.1016/j.chemgeo.2004.04.023.

Jiang, S.H., Nie, F.J., Hu, P., and Liu, Y., 2006, Important spreading event of the Neo-Tethys ocean during the Late Jurassic and Early Cretaceous: Evidence from zircon U-Pb SHRIMP dating on diabase in Nagarze, southern Tibet: Acta Geologica Sinica, v. 80, p. 522-527.

Kent, R.W., Pringle, M.S., Müller, R.D., Saunders, A.D., and Ghose, N.C., 2002, ${ }^{40} \mathrm{Ar} /{ }^{39} \mathrm{Ar}$ geochronology of the Rajmahal basalts, India, and their relationship to the Kerguelen Plateau: Journal of Petrology, v. 43, p. 1141-1153, doi: 10.1093/petrology/43.7.1141.

Kieffer, B., Arndt, N.T., and Weis, D., 2002, A bimodal alkalic shield volcano on Skiff Bank: Its place in the evolution of the Kerguelen Plateau: Journal of Petrology, v. 43, p. 1259-1286, doi: 10.1093/petrology/43.7.1259.

Lini, A., Weissert, H., and Erba, E., 1992, The Valanginian carbon isotope event: A first episode of greenhouse climate conditions during the Cretaceous: Terra Nova, v. 4, p. 374-384, doi: 10.1111/j.1365-3121.1992.tb00826.x.

Richards, M.A., Duncan, R.A., and Courtillot, V.E., 1989, Flood basalts and hotspot tracks: Plume heads and tails: Science, v. 246, p. 103-108, doi: 10.1126/science.246.4926.103.

Schettino, A., and Scotese, C.R., 2001, New internet software aids paleomagnetic analysis and plate tectonic reconstructions: Eos (Transactions, American Geophysical Union), v. 82, p. 530 536, doi: 10.1029/01EO00316.

Sheth, H., 2007, Large igneous provinces (LIPs): Definition, recommended terminology, and a hierarchical classification: Earth-Science Reviews, v. 85, p. 117-124, doi: 10.1016/j.earscirev.2007.07.005.

Storey, B.C., 1995, The role of mantle plumes in continental breakup: Case histories from Gondwanaland: Nature, v. 377, p. 301-308, doi: 10.1038/ $377301 \mathrm{a} 0$.

Wan, X.Q., Gao, L.F., Li, G.B., Chen, W., and Zhang, Y., 2005, Jurassic-Cretaceous boundary strata in Gyangze-Nagarze area: Tibet: Geoscience, v. 19 , p. $479-487$.

Weissert, H., and Erba, E., 2004, Volcanism, $\mathrm{CO}_{2}$ and palaeoclimate: A Late Jurassic-Early Cretaceous carbon and oxygen isotope record: Geological Society of London Journal, v. 161, p. 695-702, doi: 10.1144/0016-764903-087.

White, R., and McKenzie, D., 1989, Magmatism at rift zones: The generation of volcanic continental margins and flood basalts: Journal of Geophysical Research, v. 94, p. 7685-7729, doi: 10.1029/JB094iB06p07685.

Zhu, D.C., Pan, G.T., Mo, X.X., Wang, L.Q., Liao, Z.L., Jiang, X.S., and Geng, Q.R., 2005, SHRIMP U-Pb zircon dating for the dacite of the Sangxiu Formation in the central segment of Tethyan Himalaya and its implications: Chinese Science Bulletin, v. 50, p. 563-568.

Zhu, D.C., Pan, G.T., Mo, X.X., Liao, Z.L., Jiang, X.S., Wang, L.Q., and Zhao, Z.D., 2007, Petrogenesis of volcanic rocks in the Sangxiu Formation, central segment of Tethyan Himalayas: A probable example of plume-lithosphere interaction: Journal of Asian Earth Sciences, v. 29, p. 320-335, doi: 10.1016/j.jseaes.2005.12.004

Zhu, D.C., Mo, X.X., Pan, G.T., Zhao, Z.D., Dong, G.C., Shi, Y.R., Liao, Z.L., and Zhou, C.Y., 2008a, Petrogenesis of the earliest Early Cretaceous basalts and associated diabases from Cona area, eastern Tethyan Himalaya in south Tibet: Interaction between the incubating Kerguelen plume and eastern Greater India lithosphere?: Lithos, v. 100, p. 147-173, doi: 10.1016/j.lithos.2007.06.024.

Zhu, D.C., Mo, X.X., Zhao, Z.D., Niu, Y.L., and Chung, S.L., 2008b, Whole-rock elemental and zircon Hf isotopic geochemistry of mafic and ultramafic rocks from the Early Cretaceous Comei large igneous province in southeast Tibet: Constraints on mantle source characteristics and petrogenesis (extended abstract): Himalayan Journal of Sciences, v. 5, p. 178-180, doi: 10.3126/hjs.v5i7.1350.

Manuscript received 5 January 2009

Revised manuscript received 29 January 2009

Manuscript accepted 29 January 2009

Printed in USA 